\title{
The co-epidemic of Dengue and COVID-19 in Brazil: between challenges in their management and the consequences of socioeconomic inequality
}

\author{
A co-epidemia de Dengue e COVID-19 no Brasil: entre os desafios para o seu manejo e as \\ consequências da desigualdade socioeconômica \\ La coepidemia de Dengue y COVID-19 en Brasil: entre los desafíos en su manejo y las \\ consecuencias de la desigualdad socioeconómica
}

Received: 04/06/2021 | Reviewed: 04/15/2021 | Accept: 04/19/2021 | Published: 04/30/2021

Tarcísio de Freitas Milagres

ORCID: https://orcid.org/0000-0002-7397-1612 Universidade Federal do Rio Grande do Sul, Brazil

E-mail: tarcisiodefreitasmilagres@gmail.com

Wellington Junior da Silva

ORCID: https://orcid.org/0000-0001-9377-3800 Universidade Federal do Rio Grande do Sul, Brazil

E-mail: wellingtonbxo@hotmail.com

Alessandra Bittencourt de Lemos

ORCID: https://orcid.org/0000-0001-6554-2861 Universidade Federal do Rio Grande do Sul, Brazil

E-mail: aleblemos2@gmail.com

Harry Luiz Pilz Júnior

ORCID: https://orcid.org/0000-0002-3379-4885 Universidade Federal do Rio Grande do Sul, Brazil E-mail: harrypilz@gmail.com

Josiane Somariva Prophiro

ORCID: https://orcid.org/0000-0002-1840-1115

Universidade do Sul de Santa Catarina, Brazil E-mail: josiane.prophiro@hotmail.com

Onilda Santos da Silva

ORCID: https://orcid.org/0000-0003-4806-8285 Universidade Federal do Rio Grande do Sul, Brazil E-mail: onilda.santos@gmail.com

\begin{abstract}
SARS-CoV-2, the etiological agent of COVID-19, spread worldwide, reaching pandemic status in March 2020. In this scenario, dengue epidemics continue to impact endemic countries. Taking into account an increase in dengue cases worldwide, the COVID-19 pandemic may signal a serious danger to global public health. In some countries the pandemic coincided with already installed dengue epidemics. Thus, understanding the collective constituents of arboviruses in pandemic times is fundamental for a significant analysis. The present work brings a narrative review elucidating important impacts resulting from the co-epidemic and its consequences in a broader perspective. Problems with the differential diagnosis of these infections are aggravating factors for the decision of clinical management and prognosis of infected individuals. In addition, socioeconomic characteristics and ethnicity are fundamental factors for both dengue transmission dynamics and COVID-19. It also stands out, a scenario that represents a high risk of collapse for health services in facing challenges for combating and managing resources. Therefore, we conclude that in order to overcome the crisis of simultaneous epidemics and their serious consequences, historical aspects and their relationship with the conditions of social vulnerability need to be taken into account, in addition to promoting specific actions for their combat.
\end{abstract}

Keywords: COVID-19; Dengue; Arboviruses; Pandemic; Neglected tropical diseases.

\section{Resumo}

O SARS-CoV-2, agente etiológico da COVID-19, se espalhou pelo mundo, atingindo o status de pandemia em março de 2020. Neste cenário, as epidemias de dengue continuam a impactar os países endêmicos. Levando em consideração o aumento dos casos de dengue em todo o mundo, a pandemia de COVID-19 pode sinalizar um sério perigo para a saúde pública global. Em alguns países, a pandemia coincidiu com epidemias de dengue já instaladas. Assim, compreender os constituintes coletivos das arboviroses em tempos de pandemia é fundamental para uma análise significativa. O presente trabalho traz uma revisão narrativa elucidando impactos importantes decorrentes da coepidemia e suas consequências em uma perspectiva mais ampla. Problemas com o diagnóstico diferencial dessas 
infecções são fatores agravantes para a decisão do manejo clínico e prognóstico dos indivíduos infectados. Além disso, as características socioeconômicas e etnia são fatores fundamentais tanto para a dinâmica de transmissão da dengue quanto para a COVID-19. Destaca-se também, um cenário que representa alto risco de colapso para os serviços de saúde no enfrentamento dos desafios para o combate e gestão de recursos. Conclui-se, portanto que, para superar a crise das epidemias simultâneas e suas graves consequências, devem ser considerados os aspectos históricos e sua relação com as condições de vulnerabilidade social, além da promoção ações específicas para o seu combate.

Palavras-chave: COVID-19; Dengue; Arboviroses; Pandemia; Doenças tropicais negligenciadas.

\section{Resumen}

El SARS-CoV-2, el agente etiológico de COVID-19, se propagó por todo el mundo y alcanzó el estado de pandemia en marzo de 2020. En este escenario, las epidemias de dengue continúan afectando a los países endémicos. Teniendo en cuenta un aumento de los casos de dengue en todo el mundo, la pandemia de COVID-19 puede indicar un grave peligro para la salud pública mundial. En algunos países, la pandemia coincidió con epidemias de dengue ya instaladas. Por lo tanto, comprender los componentes colectivos de los arbovirus en tiempos de pandemia es fundamental para un análisis significativo. El presente trabajo trae una revisión narrativa que aclara los impactos importantes resultantes de la co-epidemia y sus consecuencias en una perspectiva más amplia. Los problemas con el diagnóstico diferencial de estas infecciones son factores agravantes para la decisión de manejo clínico y pronóstico de los individuos infectados. Además, las características socioeconómicas y la etnia son factores fundamentales tanto para la dinámica de transmisión del dengue como para el COVID-19. También se destaca, escenario que representa un alto riesgo de colapso de los servicios de salud ante los desafíos de combate y gestión de recursos. Por tanto, concluimos que para superar la crisis de epidemias simultáneas y sus graves consecuencias, es necesario tener en cuenta los aspectos históricos y su relación con las condiciones de vulnerabilidad social, además de promover acciones específicas para su combate.

Palabras clave: COVID-19; Dengue; Arbovirus; Pandemia; Enfermedades tropicales desatendidas.

\section{Introduction}

In December 2019, numerous health units in China began reporting the presence of unknown pneumonia conditions in certain groups of patients who had a common link to a seafood and animal market in Wuhan, capital of Hubei Province, China. In the investigation, researchers showed that it was a virus of the Coronavidae family, closely related to Severe Acute Respiratory Syndrome (SARS) and Middle East Respiratory Syndrome (MERS) (Guan et al., 2020; Lu et al., 2020; Zhu et al., 2020). The virus called SARS-CoV-2, etiological agent of COVID-19 (Gorbalenya et al., 2020) had spread very quickly worldwide, reaching pandemic status on March 12, 2020 (World Health Organization, 2020c). As of January 13, 2021, a total of 90.335.008 cases and 1.954.336 deaths were confirmed worldwide (WHO - World Health Organization, 2020b), while in Brazil there were 8.256.536 cases and 205.964 deaths to date (Ministério da Saúde, 2020b).

In the last 20 years an eight-fold increase in the overall incidence of dengue cases has been reported to WHO. In 2000, 505.430 cases were reported and in 2019 this number rose to about 4.2 million (World Health Organization, 2020a). Epidemics of this disease continue to impact endemic countries, given that the high population density of certain sites is an aggravating factor when thinking of simultaneous transmission with COVID-19 (Rocklöv \& Sjödin, 2020; Wilder-Smith et al., 2019). Taking into account an increase in dengue cases worldwide, the COVID-19 pandemic may signal a major danger to global public health (Ridwan, 2020).

Further aggravating the situation, an increased in the number of dengue cases in 2020 compared to 2019, was reported in Bolivia, Honduras, Mexico, Paraguay and Brazil, as well as southeast and south Asia, further aggravating the situation. Thus, the risk of simultaneous infection with COVID-19 became imminent (Pan American Health Organization, 2020). Later Ridwan (2020), demonstrated that the pandemic coincided with a dengue epidemic already installed in south and southeast Asia, Africa and Latin America, and later Europe and East Asia (Pan American Health Organization, 2020). This scenario poses a risk of collapse for health services, facing challenges in combating and managing resources, as well as greater risk to the infected people (Miah \& Husna, 2020). The co-epidemic can have devastating effects for tropical and subtropical regions (Wilder-Smith et al., 2020), as reported in several cities in Peru, where double viral load has been described with high 
mortality rates (Rodriguez-Morales et al., 2020).

In Brazil, in addition to the impacts resulting from the COVID-19 pandemic, which presented more than 8.25 million confirmed cases and continues to grow alarmingly (Ministério da Saúde, 2020b), epidemics of arboviruses also had great consequences. There was an increase in the number of probable cases of dengue (979.764), chikungunya (80.914) and zika (7.119), from December/2019 to December/2020 (Ministério da Saúde, 2020a).

The simultaneous occurrence of COVID-19 and dengue outbreaks threatens public health and socioeconomic conditions in several ways, which makes efforts to prevent, detect and treat infectious diseases even more important (Rahi et al., 2020). For example, for dengue in the absence of drugs and vaccines, the use of insecticides becomes the main measure adopted for control programs (Braga \& Valle, 2007). However, they can cause several toxic effects (Hodgson \& Levi, 1996) inducing, for example, Immune disorders (Skolarczyk et al., 2017), which in turn, could indirectly affect a COVID-19 infection making people more vulnerable (Braga \& Valle, 2007; Hodgson \& Levi, 1996; Skolarczyk et al., 2017). Corroborating the seriousness of this problem, there is the possibility of a cross-reactivity between diagnostic tests for dengue virus infections and the new coronavirus. When comparing the geographic distribution of SARS-CoV-2 with dengue outbreaks in 2019 and 2020, it is observed that places where there is a low rate of SARS-CoV-2 and a slower evolution of the spread of COVID-19 are the same ones that suffered an intense dengue crisis in these years. This was confirmed by the identification of significant negative correlations between COVID-19's incidence, infection growth rate, and mortality to the percentage of people with antibody levels for dengue fever in each of the country's states, suggesting a possibility of an immunological cross-reactivity between DENV serotypes and SARS-CoV-2 (Nicolelis et al., 2020). Even if diagnostic tests for SARS-CoV-2 infections are limited and the true number of cases is unknown, in the same period there is an increase in the number of cases and deaths from COVID-19 (Magalhaes et al., 2020).

Deaths resulting from the rapid global expansion of pathogens, such as the recent emergence of the new coronavirus (SARS-CoV-2) and also some arboviruses, emphasize the importance of infectious diseases and the need to clarify factors related to the emergence and its consequences (Burkett-Cadena \& Vittor, 2018). Although there are still numerous unknown cases, the developing scenario is predictable in many ways, as similar situations have already been evidenced and are likely to happen again (Murdoch \& French, 2020). Thus, the objective of this work was to carry out a narrative review in order to understand the crisis of the co-epidemic of dengue and COVID-19 and its consequences in a broader perspective, considering the social determinants of the health-disease process of both.

\section{Methodology}

For the production of this narrative review (Cook \& Haynes, 1997) searches were carried out in several databases and keywords were chosen: Dengue; Pandemic; COVID-19; Arboviruses; Neglected Tropical Diseases, Mosquitoes and Social Inequality. All articles that contained information relevant to the purpose of the review were selected and used for their construction. No temporal delimitation was made for the inclusion of the articles, aiming at a greater range of results that could be used.

\section{Social Panorama of Dengue, Other Arboviruses and COVID-19}

Currently, in urban and periurban locations the viruses with the highest transmissibility by mosquitoes such as Aedes aegypti, are dengue virus DENV 1-4, zika virus ZIKV and chikungunya virus CHIKV. The diseases caused by those agents cause enormous burden sums for health services and injuries for the Brazilian population (de Brito \& Cordeiro, 2016). Especially in countries that are endemic to dengue there is a recurrence of outbreaks and in these places hemorrhagic dengue is 
one of the main causes of morbidity and mortality (Miah \& Husna, 2020). Almost half of the world's population may be at risk of becoming infected with dengue viral serotypes, especially those living in tropical and sub-tropical climate regions (Bhatt et al., 2013). Every year, approximately 100 million dengue cases occur with high rates mainly in Southeast Asia and Latin America (Wilder-Smith et al., 2019). People living in endemic countries to arboviruses in general live with the impact of loss of life and family suffering on a daily basis, so the continuous transmission of these diseases should not be neglected (LaBeaud, 2008).

It is noteworthy that in places with few socioeconomic resources, arboviruses are an evident health problem, and they are part of the maintenance of poverty in tropical countries (LaBeaud, 2008). The precarious living and housing conditions are important factors related to the occurrence of arboviruses (Sanders et al., 1999), since the life cycle of vector mosquitoes, especially A. aegypti, is provided by environments that permeate precarious urban housing (Burky, 2020; Friel et al., 2004; Lifson, 1996). Reemerging diseases such as yellow fever and Japanese encephalitis have been described in poor neighborhoods (Gubler, 2002; Tomori, 2002) and lethality rates can reach 30\%, as is the case with Japanese encephalitis. In addition, most survivors live with severe neurological sequelae (Myint et al., 2007). Another study on the chikungunya virus outbreak in 2005-2006 in India suggested that poor people were most commonly affected and that loss of income during the disease led to worsening poverty (Kumar et al., 2007). Thus, if a community is unable to make adequate vector control, the spread of arboviruses becomes a consequence.

Thus, poverty provides favorable aspects to the transmissibility of diseases that afflict socioeconomically vulnerable populations worldwide (LaBeaud, 2008). Population agglomeration, for example, is an important factor for both dengue and COVID-19 transmission (Rocklöv \& Sjödin, 2020; Wilder-Smith et al., 2019). Quarantine, social isolation and physical distancing apply disproportionately to different groups, as well as their impacts. The situation in any country, becomes even more drastic when it suffers the destructive effects of great political instability and of government officials with an approach to public health that is hostile to evidence, adopting positions that deny scientific evidence, which has been fatal for the thousands of people facing structural inequalities (Ortega \& Orsini, 2020).

If we look at the geographic and ethnic regions, we observe that the brown and black population, about $50 \%$ of Brazilians, is more vulnerable to social and environmental determinants (Baqui et al., 2020; Price-Haywood et al., 2020; Ravi, 2020; Ribeiro et al., 2020). After the age group, brown ethnicity was considered the second largest risk factor for mortality. In addition, patients from the North region have a higher risk of death from COVID-19 when compared to the central-south region, except for the city of Rio de Janeiro (Baqui et al., 2020). In Manaus, capital of the state of Amazonas, northern region of the country, due to the great demand and consequent overload of hospitals, positive patients for COVID-19 were sent home due to the unavailability of beds, resulting in the death of many of them. The situation was critical to the point that it was necessary to use excavators to build graves more quickly so that there was room for corpses, previously lined up in hospital corridors (Meyerfeld, 2020). However, it is noteworthy that pandemic mitigation measures were not being carried out at this time in Manaus. The northeastern region of the country was also heavily affected with high incidence rates of COVID-19 (Ministério da Saúde, 2020b).

In these regions there are more conditions that favor the circulation of respiratory pathogens, such as the large number of precarious housing and a higher average number of individuals per room (Ribeiro et al., 2020). In addition, the north and northeast regions have lower percentages of the urban population served by piped and treated water (Ministério do Desenvolvimento Regional, 2019), which obviously makes it difficult to adhering to basic hygiene recommendations. Due to the scarcity of access to basic sanitation, socioeconomically vulnerable populations store water in residential gallons, corroborating the increase in arbovirus transmission, given that there is an increase in possible breeding sites of vector mosquitoes, such as $A$. aegypti, that with a single bite can transmit the viruses causing dengue, zika and chikungunya (Eder et 
al., 2018; Vogels et al., 2019). So the proximity of these breeding sites and precarious dwellings can act as important risk factors for arbovirus transmission (Peterson et al., 2009). Historically, arboviruses affect more the poor people and promote the maintenance of poverty in regions where they occur, being responsible for great consequences and serious impacts on quality of life. Nevertheless, epidemics caused by arboviruses such as dengue have never been a global health priority (LaBeaud, 2008; Nogueira et al., 1999; Vogels et al., 2019) which certainly qualify arboviruses as neglected diseases (LaBeaud, 2008). In Brazil, inequality of class, race and gender also influenced the zika virus epidemic, with the northeastern region being the most affected by its consequences, such as microcephaly and other neurological conditions. In addition, in this same region socioeconomically vulnerable women were the most affected, resulting in a greater demarcation of social inequality in this group (Diniz, 2016, 2017; Löwy, 2019; Paiva et al., 2020).

\section{Clinical Presentation and Diagnostic Tests}

Co-infections with dengue and COVID-19 have been reported in several dengue endemic countries, such as Singapore (Yan et al., 2020), Thailand, India (B. Joob \& Wiwanitkit, 2020) and Bangladesh (Apu, 2020). These studies open gaps to be described, as it is not yet known what this co-infection can trigger in the individual and/or community response. Co-infection represents a challenge for accurate diagnosis and treatment, especially when initial symptoms are similar to various viral diseases. The clinical and laboratory characteristics of dengue and COVID-19 are sometimes very similar and, therefore, difficult to distinguish. Fever, cough, headache and rash are common symptoms in patients with COVID-19 and very similar to those observed in dengue patients (Guan et al., 2020; Joob \& Wiwanitkit, 2020). Taking into account the possibility of similar manifestations in both diseases, the differential clinical diagnosis becomes very difficult (Ridwan, 2020), which can lead to an increase in viral dissemination (Yan et al., 2020). In Thailand, a case of coinfection was reported, in which a patient initially diagnosed with dengue, therefore without respiratory precautions, was later diagnosed with SARS-CoV-2 infection, and eventually transmitted COVID-19 to a health professional (Joob \& Wiwanitkit, 2020).

False-positive results for dengue in the rapid test may also occur in SARS-CoV-2 infection. In Singapore, two patients were diagnosed as positive for dengue, later positive for COVID-19. However, after the application of the RT-PCR method, they were negative for dengue (Yan et al., 2020). In view of the chance of co-infections or circulation regions of several viral species, it is indispensable to correctly diagnose these infections and adequate clinical management for disease prevention (de Brito \& Cordeiro, 2016). To facilitate the initial differential clinical diagnosis, some authors have shown certain differences between both infections: the presentation of COVID-19 with symptoms of cough in $>75 \%$, with up to $25 \%$ of patients presenting productive cough (Thomas-Rüddel et al., 2020), sore throat and nose symptoms, unusual findings in dengue, in relation to laboratory findings, monocytosis, lymphopenia and thrombocytopenia are more common in dengue (Yan et al., 2018). However, in Thailand, a patient with COVID-19, diagnosed by RT-PCR, presented fever, petechiae and thrombocytopenia (Joob \& Wiwanitkit, 2020), which are common for dengue (Yan et al., 2018). However, both infections present similar laboratory parameters at the beginning, such as lymphopenia, leukopenia, thrombocytopenia and elevated transaminases (Yan et al., 2020).

These false-positive tests for dengue cause a delay in the diagnosis of COVID-19 infection, as well as the chance of co-infection can also lead to a delay in correct diagnosis. Therefore, both factors have as a consequence the increase in the spread and transmission of the pandemic virus and/or severe evolution of the individual infected by such viruses (SaavedraVelasco et al., 2020). 


\section{Overloading Health Systems}

Simultaneous dengue and COVID-19 epidemics in Latin America (Burky, 2020; Saavedra-Velasco et al., 2020) and the risk of coinfection further increase the burden of health systems (Ridwan, 2020), as observed in Brazil (Lorenz et al., 2020) and Ecuador (Navarro et al., 2020). Recent increases in the incidence of severe cases of dengue, zika and chikungunya may increase the burden of vacancies in intensive care unit (ICU) beds, corroborating concern about the saturation of health services due to the occupation caused by the SARS-CoV-2 pandemic (Navarro et al., 2020). Health systems around the world are experiencing a period of constant pressure due to the current COVID-19 pandemic, with repercussions on the outcome of other diseases that perpetuate, as in the case of arboviruses. This has occurred, considering that resources in health, financial and personnel are being diverted to the containment of the pandemic (Rahi et al., 2020; Wilder-Smith et al., 2020). However, the World Health Organization emphasizes that efforts to maintain actions to combat vector-borne diseases are indispensable during this pandemic period (Rahi et al., 2020).

Another limiting factor faced in the fight against the vector mosquito in Brazil is related to difficulties in harmonizing the work of home visits performed by health teams, which aim at the application of larvicides to control the populations of $A$. aegypti in urban centers. There is also health education, with the need for social isolation of the population due to the current pandemic. The National Council of Health Secretariats (CONASEMS) in partnership with the National Council of Health Secretaries (CONASS) has published a specific guide for this confrontation (CONASEMS \& CONASS, 2020).

\section{The Effects of Physical Distancing on the Potential of Dengue Transmission in Brazil}

Physical distancing (PD) has been and is being implemented worldwide aiming at reducing the transmission of COVID-19 among individuals from a population (Prem et al., 2020). The PD in Brazil was implemented at the end of March 2020, in some states, after the significant increase in the number of deaths due to COVID-19, being implemented through the suspension of events, face-to-face classes in schools/universities, total/partial economic lockdown, population quarantine (travel restriction, risk groups) (Da Silva et al., 2020).

However, the effect of this measure may have had a great impact on the transmission of other viruses, such as DENV, since human mobility itself at the spatial level and patterns of home and workplace infections are determinant for vector-borne diseases (Van Panhuis et al., 2015). Thus, the PD, in a way, acts on these determinants and suggests a strong association with the transmission rate. Lim et al., (2020), in order to establish an association of PD and its influence on DENV transmission rates, studied the data of infection by COVID-19 and DENV over time in regions of Asia and suggested that PD had a strong impact on dengue cases and attributed to the fact that individuals spent more time in their homes than in workplaces. In addition, the authors suggest that home conditions may be worse than at work, which would result in a higher rate of mosquito infestation.

\section{Final Considerations}

In endemic countries to dengue, there is a high risk of possible co-infections and co-epidemics. Co-infections can cause diseases with overlapping signs and symptoms that make diagnosis and treatment more complicated, which translates into a major public health concern (Miah \& Husna, 2020) especially in relation to peripheral areas and low-income communities where sanitation, hygiene and medical access measures are commonly scarce. These issues require urgent attention, since cases of infection and deaths from COVID-19 remain underdiagnosed due to lack of resources, which hinders the containment of viral dissemination ( $\mathrm{Li}$ et al., 2020), causing strong consequences in the health system, public health and social condition (Ribeiro et al., 2020). Due to the unequal spread in dense population areas and poor access to public health 
programs, COVID-19, dengue and other arboviruses such as Zika and, are disproportionately affecting the poor population, the most vulnerable groups and regions. (Shadmi et al., 2020).

The occurrence of inaccurate clinical diagnoses and cross-reaction serological results may influence official notifications by the Brazilian government, as well as the clinical management of infections may not be appropriate (Magalhaes et al., 2020). In some tropical and subtropical countries, the dengue epidemic should be taken into account during the analysis of mortality rates, which should not be attributed exclusively to COVID-19 (Rodriguez-Morales et al., 2020). Thus, using strategies considering the epidemiological and contact history of the patient, combined with knowledge of the possibility of false-positive serological tests for dengue and the possibility of co-infections, are essential for health professionals (Ridwan, 2020).

Although health teams are redirected to cope with the current pandemic, vector mosquito control measures should continue to be encouraged. Olive et al., (2020) emphasize the importance of maintaining and strengthening integrated management of mosquito-borne diseases. Thus, it is essential to guarantee Adequate Individual Protective Equipment to health workers who actively participate in screening, environmental management, insecticide spraying, home care for the elimination of breeding sites and health education actions. In the period of physical isolation, the community should be oriented to carry out actions to combat mosquitoes at home and peridomicile, being places of greater importance to prevent outbreaks of arboviruses, especially dengue (Wilder-Smith et al., 2020). In addition, places such as schools, cemeteries and construction sites, probably with little movement of people during the period of isolation, should be frequently inspected so that there is no accumulation of breeding sites and thus prevent new outbreaks of mosquito-borne diseases when there is a return of activities and crowding of people in these spaces (Liang et al., 2018; Louis et al., 2016). The needs for maintaining efforts for the prevention, detection and treatment of vector-borne diseases emphasized by the World Health Organization should be maintained during (Rahi et al., 2020) and after the pandemic.

These diseases transcend the health sphere, reaching social groups in different ways, since some of them are systematically at a disadvantage in relation to the opportunity to remain healthy. If we had learned before, with dengue and so many other arboviruses, about the need for health actions aimed at specific groups, and how fundamental it is to exercise citizenship and social participation, the effects of COVID-19 and many other diseases would be much less drastic. The importance of adopting an intersectoral view and understanding of the disease production process in different social contexts is fundamental. Thus, it will be possible to increase the chances of obtaining effective control of both dengue and COVID-19.

\section{References}

Apu, S. M. (2020). A double struggle: Home ministry PRO battling Covid-19, dengue. The Daily Star. https://www.thedailystar.net/coronavirus-deadly-newthreat/news/double-struggle-home-ministry-pro-battling-covid-19-dengue-1905013

Baqui, P., Bica, I., Marra, V., Ercole, A., \& van der Schaar, M. (2020). Ethnic and regional variations in hospital mortality from COVID-19 in Brazil: a crosssectional observational study. The Lancet Global Health, 8(8), e1018-e1026.

Bhatt, S., Gething, P. W., Brady, O. J., Messina, J. P., Farlow, A. W., Moyes, C. L., Drake, J. M., Brownstein, J. S., Hoen, A. G., Sankoh, O., Myers, M. F., George, D. B., Jaenisch, T., Wint, G. R. W., Simmons, C. P., Scott, T. W., Farrar, J. J., \& Hay, S. I. (2013). The global distribution and burden of dengue. Nature, 496(7446), 504-507.

Braga, I. A., \& Valle, D. (2007). Aedes aegypti: histórico do controle no Brasil* Aedes aegypti: History of Control in Brazil. Epidemiologia e Serviços de Saúde 2007, 16(2), 113-118.

Burkett-Cadena, N. D., \& Vittor, A. Y. (2018). Deforestation and vector-borne disease: Forest conversion favors important mosquito vectors of human pathogens. Basic and Applied Ecology, 26, 101-110.

Burky, T. (2020). COVID-19 in Latin America. PubMed, January, 547-548.

Conasems, C. N. dos S. M. de S., \& Conass, C. N. dos S. de S. (2020). Guia Orientador para o enfrentamento da pandemia Covid-19 na Rede de Atenção à Saúde. $89 . \quad$ https://www.conasems.org.br/guia-orienta-estados-e-municipios-para-o-enfrentamento-da-pandemia-de-covid-19-na-rede-de-atencao-asaude/instrumento-orientador-conass-conasems-versao-final-3/ 
Cook, D. J., Mulrow, C. D., \& Haynes, R. B. (1997). Systematic reviews: synthesis of best evidence for clinical decisions. Annals of internal medicine, 126(5), 376-380.

Da Silva, L. L. S., Lima, A. F. R., Polli, D. A., Razia, P. F. S., Pavão, L. F. A., De Hollanda Cavalcanti, M. A. F., \& Toscano, C. M. (2020). Social distancing measures in the fight against covid-19 in brazil: Description and epidemiological analysis by state. Cadernos de Saude Publica, 36(9), 1-15.

de Brito, C. A. A., \& Cordeiro, M. T. (2016). One year after the Zika virus outbreak in Brazil: From hypotheses to evidence. Revista Da Sociedade Brasileira de Medicina Tropical, 49(5), 537-543.

Diniz, D. (2016). Vírus Zika e mulheres. Cadernos de Saude Publica, 32(5), 1-4.

Diniz, D. (2017). Zika: From the Brazilian backlands to global threat. Zed Books, 132-135.

Eder, B., Bissinger, A., Riessen, R., \& Haap, M. (2018). Malaria tropica und Dengue-Fieber - eine Herausforderung der Intensivmedizin. Intensivmedizin Up2date, 14(03), 263-278.

Friel, S., McMichael, A., Kjellstrom, T., \& Prapamontol, T. (2004). Housing and health transition in Thailand. Rev Environ Health, 19, 311-327.

Gorbalenya, A., Baker, S., Baric, R., de Groot, R., Drosten, C., Gulyaeva, A., Haagmans, B., Lauber, C., Leontovich, A., Neuman, B., Penzar, D., Perlman, S., Poon, L., Samborskiy, D., Sidorov, I., Sola, I., \& Ziebuhr, J. (2020). Severe acute respiratory syndrome-related coronavirus : The species and its viruses - a statement of the Coronavirus Study Group. Nature Microbiology.

Guan, W., Ni, Z., Hu, Y., Liang, W., Ou, C., He, J., Liu, L., Shan, H., Lei, C., Hui, D. S. C., Du, B., Li, L., Zeng, G., Yuen, K.-Y., Chen, R., Tang, C., Wang, T., Chen, P., Xiang, J., ... Zhong, N. (2020). Clinical Characteristics of Coronavirus Disease 2019 in China. New England Journal of Medicine, $382(18)$, $1708-1720$

Gubler, D. J. (2002). The global emergence/resurgence of arboviral diseases as public health problems. Archives of Medical Research, 33(4), 330-342.

Hodgson, E., \& Levi, P. E. (1996). Pesticides: An important but underused model for the environmental health sciences. Environmental Health Perspectives, 104(SUPPL. 1), 97-106.

Joob, B., \& Wiwanitkit, V. (2020). COVID-19 in medical personnel: observation from Thailand. Journal of Hospital Infection, 104(4), 453.

Joob, Beuy, \& Wiwanitkit, V. (2020). COVID-19 can present with a rash and be mistaken for dengue. Journal of the American Academy of Dermatology, $82(5), \mathrm{e} 177$.

Kumar, C. J., Baboo, C. A., Krishnan, B. U., Kumar, A., Joy, S., Jose, T., Philip, A., Sambasivaiah, K., \& Hegde, B. M. (2007). The socioeconomic impact of the chikungunya viral epidemic in India. Open Medicine (Ottawa), 1(3), 150-152.

LaBeaud, A. D. (2008). Why arboviruses can be neglected tropical diseases. PLoS Neglected Tropical Diseases, 2(6), 1-2.

Li, R., Pei, S., Chen, B., Song, Y., Zhang, T., Yang, W., \& Shaman, J. (2020). Substantial undocumented infection facilitates the rapid dissemination of novel coronavirus (SARS-CoV-2). Science, 368(6490), 489-493.

Liang, S., Hapuarachchi, H. C., Rajarethinam, J., Koo, C., Tang, C. S., Chong, C. S., Ng, L. C., \& Yap, G. (2018). Construction sites as an important driver of dengue transmission: Implications for disease control. BMC Infectious Diseases, 18(1), 1-10.

Lifson, A. (1996). Mosquitoes, models, and dengue. The Lancet, 142, 1201-1202.

Lim, J. T., Dickens, B. S. L., Chew, L. Z. X., Choo, E. L. W., Koo, J. R., Aik, J., Ng, L. C., \& Cook, A. R. (2020). Impact of SARS-CoV-2 interventions on dengue transmission. PLoS Neglected Tropical Diseases, 14(10), 1-17.

Lorenz, C., Azevedo, T. S., \& Chiaravalloti-Neto, F. (2020). COVID-19 and dengue fever: A dangerous combination for the health system in Brazil. Travel Medicine and Infectious Disease, 35(January), 19-21.

Louis, V. R., Montenegro Quiñonez, C. A., Kusumawathie, P., Palihawadana, P., Janaki, S., Tozan, Y., Wijemuni, R., Wilder-Smith, A., \& Tissera, H. A. (2016). Characteristics of and factors associated with dengue vector breeding sites in the City of Colombo, Sri Lanka. Pathogens and Global Health, 110(2),

Löwy, I. (2019). Zika No Brasil: História Recente De Uma Epidemia (Scielo-E).

Lu, R., Zhao, X., Li, J., Niu, P., Yang, B., Wu, H., Wang, W., Song, H., Huang, B., Zhu, N., Bi, Y., Ma, X., Zhan, F., Wang, L., Hu, T., Zhou, H., Hu, Z., Zhou, W., Zhao, L., ... Tan, W. (2020). Genomic characterisation and epidemiology of 2019 novel coronavirus: implications for virus origins and receptor binding. The Lancet, 395(10224), 565-574.

Magalhaes, T., Chalegre, K. D. M., Braga, C., \& Foy, B. D. (2020). The Endless Challenges of Arboviral Diseases in Brazil. Tropical Medicine and Infectious Disease, 5(2), 1-6.

Meyerfeld, B. (2020). Coronavirus: au Brésil, «nous sommes à la limite de la barbarie». Le Monde. https://www.lemonde.fr/international/article/2020/04/24/coronavirus-au-bresil-nous-sommes-a-la-limite-de-la-barbarie_6037594_3210.html\#: :text=de Covid-19-,Coronavirus \%3A au Brésil\%2C «nous sommes à la limite de,à un tel défi sanitaire.

Miah, M. A., \& Husna, A. (2020). Coinfection, coepidemics of COVID-19, and dengue in dengue-endemic countries: A serious health concern. Journal of Medical Virology.

Ministério da Saúde. (2020a). Monitoramento dos casos de Arboviroses urbanas transmitidas pelo Aedes (dengue, chikungunya e Zika). Boletim Epidemiológico Arboviroses, 51(24), 1-13. https://portalarquivos2.saude.gov.br/images/pdf/2020/janeiro/20/Boletim-epidemiologico-SVS-02-1-.pdf 
Ministério da Saúde. (2020b). Painel Coronavírus. https://covid.saude.gov.br/

Ministério do Desenvolvimento Regional. (2019). Diagnóstico dos Serviços de Água e Esgotos - 2018. Sistema Nacional de Informações Sobre Saneamento. http://www.snis.gov.br/diagnostico-anual-agua-e-esgotos/diagnostico-dos-servicos-de-agua-e-esgotos-2018

Murdoch, D. R., \& French, N. P. (2020). COVID-19 : another infectious animal-human interface. Nzmj, 133(1510), 12-15.

Myint, K. S. A., Gibbons, R. V., Perng, G. C., \& Solomon, T. (2007). Unravelling the neuropathogenesis of Japanese encephalitis. Transactions of the Royal Society of Tropical Medicine and Hygiene, 101(10), 955-956.

Navarro, J. C., Arrivillaga-Henríquez, J., Salazar-Loor, J., \& Rodriguez-Morales, A. J. (2020). COVID-19 and dengue, co-epidemics in Ecuador and other countries in Latin America: Pushing strained health care systems over the edge. Travel Medicine and Infectious Disease, 37(March), 101656.

Nicolelis, M. A. L., Raimundo, R. L. G., Peixoto, P. S., \& De Andreazzi, C. S. (2020). How Super-Spreader Cities, Highways, Hospital Bed Availability, and Dengue Fever Influenced the Covid-19 Epidemic in Brazil. MedRxiv, 2020.09.19.20197749.

Nogueira, R. M. R., Miagostovich, M. P., Schatzmayr, H. G., Dos Santos, F. B., De Araújo, E. S. M., De Filippis, A. M. B., De Souza, R. V., Zagne, S. M. O., Nicolai, C., Baran, M., \& Teixeira Filho, G. (1999). Dengue in the State of Rio de Janeiro, Brazil, 1986-1998. Memorias Do Instituto Oswaldo Cruz, 94(3), 297-304.

Olive, M. M., Baldet, T., Devillers, J., Fite, J., Paty, M. C., Paupy, C., Quénel, P., Quillery, E., Raude, J., Stahl, J. P., Thiann-Bo-morel, M., \& Roiz, D. (2020). The COVID-19 pandemic should not jeopardize dengue control. PLoS Neglected Tropical Diseases, 14(9), 1-7.

Ortega, F., \& Orsini, M. (2020). Governing COVID-19 without government in Brazil: Ignorance, neoliberal authoritarianism, and the collapse of public health leadership. Global Public Health, 1-21.

Paiva, C. H. A., Teixeira, L. A. da S., \& Pires-Alves, F. A. (2020). Especial Covid-19: O Sistema Único de Saúde e o desafio da Covid-19. Fiocruz. http://www.coc.fiocruz.br/index.php/pt/todas-as-noticias/1803-osistema-unico-de-saude-e-o-desafio-da-covid-19.html\#.X9IZK1VKjIU

Pan American Health Organization. (2020). Epidemiological Update Dengue. February, 1-21.

Peterson, I., Borrell, L. N., El-Sadr, W., \& Teklehaimanot, A. (2009). A temporal-spatial analysis of malaria transmission in Adama, Ethiopia. American Journal of Tropical Medicine and Hygiene, 81(6), 944-949.

Prem, K., Liu, Y., Russell, T. W., Kucharski, A. J., Eggo, R. M., Davies, N., Flasche, S., Clifford, S., Pearson, C. A. B., Munday, J. D., Abbott, S., Gibbs, H., Rosello, A., Quilty, B. J., Jombart, T., Sun, F., Diamond, C., Gimma, A., van Zandvoort, K., ... Klepac, P. (2020). The effect of control strategies to reduce social mixing on outcomes of the COVID-19 epidemic in Wuhan, China: a modelling study. The Lancet Public Health, 5(5), e261-e270.

Price-Haywood, E. G., Burton, J., Fort, D., \& Seoane, L. (2020). Hospitalization and Mortality among Black Patients and White Patients with Covid-19. New England Journal of Medicine, 382(26), 2534-2543.

Rahi, M., Das, P., \& Sharma, A. (2020). COVID-19 mitigation steps provide a blueprint for malaria control and elimination. American Journal of Tropical Medicine and Hygiene, 103(1), 28-30.

Ravi, K. (2020). Ethnic disparities in COVID-19 mortality: are comorbidities to blame? The Lancet, $396(10243), 22$.

Ribeiro, H., Lima, V. M., \& Waldman, E. A. (2020). In the COVID-19 pandemic in Brazil, do brown lives matter? The Lancet Global Health, 8(8), e976e977.

Ribeiro, V. S. T., Telles, J. P., \& Tuon, F. F. (2020). Arboviral diseases and COVID-19 in Brazil: Concerns regarding climatic, sanitation, and endemic scenario. Journal of Medical Virology, 92(11), 2390-2391.

Ridwan, R. (2020). COVID-19 and dengue: a deadly duo. Tropical Doctor, 50(3), 270-272.

Rocklöv, J., \& Sjödin, H. (2020). High population densities catalyse the spread of COVID-19. Journal of Travel Medicine, 27(3), 1-2.

Rodriguez-Morales, A. J., Gallego, V., Escalera-Antezana, J. P., Méndez, C. A., Zambrano, L. I., Franco-Paredes, C., Suárez, J. A., Rodriguez-Enciso, H. D., Balbin-Ramon, G. J., Savio-Larriera, E., Risquez, A., \& Cimerman, S. (2020). COVID-19 in Latin America: The implications of the first confirmed case in Brazil. Travel Medicine and Infectious Disease, 35.

Saavedra-Velasco, M., Chiara-Chilet, C., Pichardo-Rodriguez, R., Grandez-Urbina, A., \& Inga-Berrospi, F. (2020). [Coinfection between dengue and covid19: need for approach in endemic zones.]. Revista de La Facultad de Ciencias Medicas (Cordoba, Argentina), 77(1), 52-54.

Sanders, E. J., Rwaguma, E. B., Kawamata, J., Kiwanuka, N., Lutwama, J. J., Ssengooba, F. P., Lamunu, M., Najjemba, R., Were, W. A., Bagambisa, G., \& Campbell, G. L. (1999). O'nyong-nyong fever in south-central Uganda, 1996-1997: Description of the epidemic and results of a household-based seroprevalence survey. Journal of Infectious Diseases, 180(5), 1436-1443.

Shadmi, E., Chen, Y., Dourado, I., Faran-Perach, I., Furler, J., Hangoma, P., Hanvoravongchai, P., Obando, C., Petrosyan, V., Rao, K. D., Ruano, A. L., Shi, L., Souza, L. E. de, Spitzer-Shohat, S., Sturgiss, E., Suphanchaimat, R., Uribe, M. V., \& Willems, S. (2020). Health equity and COVID-19: global perspectives. International Journal for Equity in Health, 19(104), 1-16.

Skolarczyk, J., Pekar, J., \& Nieradko-Iwanicka, B. (2017). Immune disorders induced by exposure to pyrethroid insecticides. Postepy Higieny i Medycyny Doswiadczalnej (Online), 71, 446-453. 
Research, Society and Development, v. 10, n. 5, e19810514728, 2021

(CC BY 4.0) | ISSN 2525-3409 | DOI: http://dx.doi.org/10.33448/rsd-v10i5.14728

Thomas-Rüddel, D., Winning, J., Dickmann, P., Ouart, D., Kortgen, A., Janssens, U., \& Bauer, M. (2020). Coronavirus disease 2019 (COVID-19): update for anesthesiologists and intensivists March 2020. Der Anaesthesist.

Tomori, O. (2002). Yellow fever in Africa: public health impact and prospects for control in the 21st century. Biomédica: Revista Del Instituto Nacional de Salud, 22(2), 178-210.

Van Panhuis, W. G., Choisy, M., Xiong, X., Chok, N. S., Akarasewi, P., Iamsirithaworn, S., Lam, S. K., Chong, C. K., Lam, F. C., Phommasak, B., Vongphrachanh, P., Bouaphanh, K., Rekol, H., Hien, N. T., Thai, P. Q., Duong, T. N., Chuang, J. H., Liu, Y. L., Ng, L. C., \& Cummings, D. A. T. (2015) Region-wide synchrony and traveling waves of dengue across eight countries in Southeast Asia. Proceedings of the National Academy of Sciences of the United States of America, 112(42), 13069-13074.

Vogels, C. B. F., Rückert, C., Cavany, S. M., Perkins, T. A., Ebel, G. D., \& Grubaugh, N. D. (2019). Arbovirus coinfection and co-transmission: A neglected public health concern? PLoS Biology, 17(1), 1-16.

Wilder-Smith, A., Ooi, E. E., Horstick, O., \& Wills, B. (2019). Dengue. The Lancet, 393(10169), 350-363. https://doi.org/10.1016/S0140-6736(18)32560-1 Wilder-Smith, A., Tissera, H., Ooi, E. E., Coloma, J., Scott, T. W., \& Gubler, D. J. (2020). Preventing dengue epidemics during the COVID-19 pandemic. American Journal of Tropical Medicine and Hygiene, 103(2), 570-571.

World Health Organization. (2020a). Dengue and severe dengue - Global burden of dengue. https://www.who.int/news-room/fact-sheets/detail/dengue-andsevere-dengue

World Health Organization. (2020b). Painel do WHO Coronavirus Disease (COVID-19). https://covid19.who.int/

World Health Organization. (2020c). WHO announces COVID-19 outbreak a pandemic. https://www.euro.who.int/en/health-topics/healthemergencies/coronavirus-covid-19/news/news/2020/3/who-announces-covid-19-outbreak-a-pandemic

Yan, G., Lee, C. K., Lam, L. T. M., Yan, B., Chua, Y. X., Lim, A. Y. N., Phang, K. F., Kew, G. Sen, Teng, H., Ngai, C. H., Lin, L., Foo, R. M., Pada, S., Ng, L. C., \& Tambyah, P. A. (2020). Covert COVID-19 and false-positive dengue serology in Singapore. The Lancet Infectious Diseases, $20(5), 536$.

Yan, G., Pang, L., Cook, A. R., Ho, H. J., Win, M. S., Khoo, A. L., Wong, J. G. X., Lee, C. K., Yan, B., Jureen, R., Ho, S. S., Lye, D. C., Tambyah, P. A., Leo, Y. S., Fisher, D., Oon, J., Bagdasarian, N., Chow, A., Smitasin, N., \& Chai, L. Y. A. (2018). Distinguishing zika and dengue viruses through simple clinical assessment, Singapore. Emerging Infectious Diseases, 24(8), 1565-1568.

Zhu, N., Zhang, D., Wang, W., Li, X., Yang, B., Song, J., Zhao, X., Huang, B., Shi, W., Lu, R., Niu, P., Zhan, F., Ma, X., Wang, D., Xu, W., Wu, G., Gao, G. F., \& Tan, W. (2020). A Novel Coronavirus from Patients with Pneumonia in China, 2019. New England Journal of Medicine, 382(8), 727-733. 